\title{
Molecular Detection and Characterization of Niger [Guizotia abyssinica (L.f.) Cass] Phyllody Phytoplasma
}

\author{
Mahalingappa Bandakkanavara ${ }^{1 *}$, H. A. Prameela ${ }^{1}$, Santosh Mali ${ }^{2}$, S. Basavaraj ${ }^{1}$, \\ Manjunath, S. Hurakadli ${ }^{1}$, Kedarnath ${ }^{1}$ and K.T. Rangaswamy ${ }^{1}$ \\ ${ }^{1}$ Department of Plant Pathology, College of Agriculture, UAS, GKVK, \\ Bengaluru-560065, India \\ ${ }^{2}$ Department of Agricultural Entomology, College of Agriculture, UAS, GKVK, \\ Bengaluru-560065, India \\ *Corresponding author
}

\begin{abstract}
A B S T R A C T
\section{Keywords}

Molecular detection, Niger, Phyllody, Phytoplasma

Article Info

Accepted: 12 January 2019 Available Online: 10 February 2019

Niger [Guizotia abyssinica (L.f.) Cass.] is one of the important minor oilseed crops in India. Phyllody disease on niger noticed for the first time at Main Research Station, Hebbal, Bengaluru, Karnataka. The molecular detection and characterization of the phytoplasma causing niger phyllody was investigated during Kharif 2016. The causal agent of the phyllody disease was identified based on symptoms, amplification of $16 \mathrm{~S}$ rDNA of the phytoplasma by polymerase chain reaction (PCR) from infected samples, as well as by sequencing and phylogenetic analysis. The molecular detection by using nested PCR phytoplasma specific universal primers R16F2n/R16FR2 revealed the amplification of phytoplasmal specific PCR product of $1.2 \mathrm{~kb}$ fragment corresponding to the 16S rDNA. The16S rDNA sequence of niger phyllody phytoplasma had maximum nucleotide identity of 90 per cent with the 16S rDNA sequence of Cymbopogon citratus white leaf phytoplasma (KF773150.1), Alfalfa witches'-broom Phytoplasma Mes 38(KT943964.1), Sesamum indicum phyllody Phytoplasma (KY547787.1) and Vigna radiata phyllody NDL (KY439871.1).
\end{abstract}

\section{Introduction}

Niger [Guizotia abyssinica (Lf) Cass.] is one of the important minor oilseed crops in India. It is commonly known as ramtil (Punjabi), jagni or jatangi (Hindi), ramtal (Gujrati), karale or khurasani (Marathi), uhechellu (Kannada), payellu (Tamil), verrinuvvulu (Telugu), alashi (Oriya), sarguza (Bengali) and sorguja (Assamese) in different parts of the country. It is cultivated to a limited extent in Ethiopia, South Africa, East Africa, West
Indies, Zimbabve and India. India ranks first in area, production and export of niger in the world. In India it is mainly cultivated in tribal areas of Madhya Pradesh, Odisha, Bihar, Karnataka, Maharashtra and Andhra Pradesh. It is also grown over a sizeable area in certain pockets of Rajasthan, Arunachal Pradesh, Gujarat, Uttar Pradesh and Tamil Nadu.

In India, niger is planted in both 'Kharif' and 'Rabi' seasons. The area, production and productivity of niger in India is about 2.77 
lakh ha, 0.88 lakh tonnes and $319 \mathrm{~kg} / \mathrm{ha}$, respectively (Anon., 2015a). In Karnataka, niger is cultivated over an area of about 0.11 Lakh ha with a production and productivity of $0.03 \mathrm{Lakh}$ tonnes and $267 \mathrm{~kg} / \mathrm{ha}$ respectively (Anon., 2015b).

Natural occurrence of niger phyllody in Karnataka state was first reported by Rangaswamy and Muniyappa (1993) and the disease incidence ranged from 1.5 to 12 per cent. The diseased plants were characterized by the transformation of floral organs into leaf like structures. Production of phyllody flowers was seen on secondary shoots in diseased plants. Early infected plants were very much stunted in their growth.

The plants infected at later stages had some branches showing typical phyllody symptoms, while rest of branches remained apparently with normal development of flowers.

The disease was successfully transmitted by the leafhopper vector Orosius albicinctus and the association of phyllody measuring 100$800 \mathrm{~nm}$ size was also confirmed by electron microscope in ultrathin section of the phloem sieve tubes of diseased niger (Rangaswamy and Muniyappa, 1993).

\section{Materials and Methods}

\section{Collection of niger phyllody disease sample}

Leaf samples were collected from naturally infected niger plants showing typical symptoms of phyllody (shoot proliferation, reduced leaflets, shortened internodes, proliferated auxiliary shoots producing witches'-brooms, virescence, and phyllody) at the Zonal Agricultural Research Station of the University of Agricultural Sciences, Bengaluru, Karnataka (south India) during the Kharif 2016. Samples from healthy plants were collected as control.

\section{Total genomic DNA extraction}

Total nucleic acid was isolated from infected and healthy leaf tissue by modified Cetyl Trimethyl Ammonium Bromide (CTAB) (Sunard et al., 1991) method and used for PCR amplification by using degenerated oligonucleotide universal primers (Deng and Hiruki, 1991). The DNA concentrations were measured with Nanodrop Spectrophotometer.

\section{Polymerase chain reaction}

The DNA obtained was subjected to PCR amplification using primer designed to amplify $16 \mathrm{~S}$ rDNA from the infected niger plants. PCR amplifications were conducted using Phytoplasma specific universal P1(5'AAGAGTTTGATCCTGGCTCAGGA TT-3') (Deng and Hiruki, 1991) and P7 (5'CGTCCTTCATCGGCTCTT-3') (Smart et al., 1996) amplifying 1,800 bp fragment that extends from the 5 ' end of the 16S rDNA to the 5' end of the 23S rDNA, were used for the detection of Phytoplasma in a first round PCR. The universal primer pair R16F2n (5'GAAACGACTGCTAAGACTGG-3') and R16R2 (5'-TGACGGGCGGTGTG TACAAA CCCC-3), designed to amplify a $1,200 \mathrm{bp}$ portion of the 16S rRNA gene, was used for N-PCR (Lee et al., 1993).

The first round PCR and N-PCRs were carried out sequentially in a final volume of $25 \mu 1$ reactions containing $2.5 \mu \mathrm{l} 10 \mathrm{X}$ PCR buffer, $25 \mathrm{mM} \mathrm{MgCl}, 2.5 \mathrm{mM}$ each dNTPs, $20 \mathrm{mM} 1.25 \mu \mathrm{l}$ each primers, $0.1 \mu \mathrm{TTaqDNA}$ polymerase (Bangalore Genei Pvt. Ltd., Bengaluru, India) and $2 \mu \mathrm{l}$ template DNA. NPCR was done using $2 \mu \mathrm{l}$ of diluted (1:30 or 1:90) standard PCR product.

The DNA was amplified by an initial denaturation of $94^{\circ} \mathrm{C}$ for 2 min followed by 35 cycles of $94^{\circ} \mathrm{Cfor} 2 \mathrm{~min}$ denaturation, $55^{\circ} \mathrm{C}$ for 2 min primer annealing $\left(56^{\circ} \mathrm{C}\right.$ for 1 
min for $\mathrm{N}$-PCR), $72^{\circ} \mathrm{C}$ for $3 \mathrm{~min}$ primer extension, and final extension at $72^{\circ} \mathrm{C}$ for 10 $\min$.

Analysis of PCR products by agarose gel electrophoresis

Amplification was confirmed by agarose gel electrophoresis.

\section{Sequencing of amplified PCR product and} sequence analysis

The products were sent to Chromous Biotech Pvt. Ltd., Bengaluru for the sequencing by Sanger's primer walking method. Sequencing was done in both directions using forward and reverse primers. The sequences retrieved were subjected to BLAST analysis.

\section{Construction of phylogenetic tree}

The sequence homology obtained in BLAST (www.ncbi.nih.gov /BLAST) and Neighbor joining phylogenetic tree was generated using MEGA 6.06 software tool.

\section{Results and Discussion}

Symptoms of niger phyllody disease under field conditions

Plants infected with phyllody were pale green and bushy due to excessive stunting, severe reduction in leaf size, reduced internodal length, excessive axillary proliferation and floral malformation like abnormal green structures developed in place of normal flowers (Plate 1)

\section{Molecular detection of the causal agent of niger phyllody}

Standardization of PCR protocol for the detection of niger phyllody Phytoplasma

Polymerase chain reaction was employed to establish association of Phytoplasma using
Phytoplasma universal primers $\mathrm{P} 1 / \mathrm{P} 7$ and $\mathrm{N}-$ PCR primers R16F2n/R16R2 to designed to amplify Phytoplasmal $16 \mathrm{~S}$ rDNA. As the Phytoplasmal DNA was not amplified when standard PCR protocol was used as suggested by the Lee et al., (1993) the PCR protocol was slightly modified by altering the PCR conditions. Annealing temperature of $55{ }^{\circ} \mathrm{C}$ for one minute was found suitable for amplifying niger phyllody Phytoplasmal DNA as compared to $48^{\circ} \mathrm{C}$ of standard PCR protocols suggested by various earlier workers.

PCR amplification of 16S rDNA from phyllody infected niger samples

\section{PCR amplification using universal primers} P1/P7

The total DNA extracted from the symptomatic and healthyniger plants were subjected to PCR amplification using the Phytoplasma- specific universal primer pair $\mathrm{P} 1 / \mathrm{P} 7$. The PCR products were subjected to the electrophorosis in a 1.0 per cent agarose gel, stained with ethidium bromide and observed under UV transilluminator. First round PCR which did not yield expected 1.8 $\mathrm{kb}$ product from any symptomatic niger samples (data not shown). This could be due to the presence of DNA concentration below the detection limit in ethidium bromidestained agarose gel.

\section{Nested PCR analysis}

In order to identify the association of $16 \mathrm{~S}$ rDNA groups to which these Phytoplasmas belongs and also to know their relationship at the molecular level, nested PCR was performed using Phytoplasma specific universal primers R16F2n/R16FR2. When the first round PCR products were reamplified in nested PCR assay using primers $\mathrm{R} 16 \mathrm{~F} 2 \mathrm{n} / \mathrm{R} 16 \mathrm{R} 2$. A product of DNA fragment of $1.2 \mathrm{~kb}$ size was obtained in the diseased 
niger samples and a known Phytoplasma positive sample (periwinkle phyllody) but not in healthy plant sample. This indicated the association of Phytoplasmal agent with niger phyllody disease (Plate 2).

\section{Molecular characterization of niger phyllody Phytoplasma}

The 16S rDNA sequence analysis of niger phyllody Phytoplasma

The 16S rDNA nucleotide sequence of niger phyllody Phytoplasma was compared with the sequences of other Phytoplasmas obtained from the NCBI database. The16S rDNA sequence of niger phyllody Phytoplasma had maximum nucleotide identity of 90 per cent with the 16S rDNA sequence of Cymbopogon citratus white leaf Phytoplasma (KF773150.1), Alfalfa witches'-broom
Phytoplasma Mes 38(KT943964.1), Sesamum indicum phyllody Phytoplasma (KY547787.1) and Vigna radiata phyllody NDL (KY439871.1) (Table 1).

16S rDNA sequence of niger phyllody Phytoplasma was compared with the gene sequences of other Phytoplasma in the Gen Bank database (Fig. 1) and phylogenetic tree was constructed by using the software MEGA 6.06. This phylogenetic tree reveals that the niger phyllody Phytoplasma of Indian strain showed the closest relationship with Cymbopogon citratus white leaf Phytoplasma (KF773150.1).

These present findings clearly support the conclusion that, niger phyllody Phytoplasma from India is closely related to the Phytoplasma belonging to the 16SrII Phytoplasmal group.

Table.1 Phylogenetic analysis of niger16S rDNA with different Phytoplasmal strains

\begin{tabular}{|c|c|c|c|}
\hline SI. No. & Phytoplasma strain & Accession number & Max. identity (\%) \\
\hline 1 & Cymbopogon citratus white leaf & KF773150.1 & \multirow[t]{9}{*}{90} \\
\hline 2 & Alfalfa witches'-broom Phytoplasma Mes 38 & KT943964.1 & \\
\hline 3 & Sesamumindicum phyllody Phytoplasma & KY547787.1 & \\
\hline 4 & Vigna radiata phyllody $N D L$ & KY439871.1 & \\
\hline 5 & Candidatus Phytoplasma aurantifolia NS-MH-NGI & KU052821.1 & \\
\hline 6 & Brinjal little leaf GKP-B & KX689254.1 & \\
\hline 7 & Tomato big bud Phytoplasma KA-52 & KP027532.1 & \\
\hline 8 & Faba bean phyllody Phytoplasma & KP869129.1 & \\
\hline 9 & Black pepper phyllody & AY823413.1 & \\
\hline 10 & Candidatus Phytoplasma palmicola LYDM-178 & KF751387.1 & \multirow[t]{4}{*}{82} \\
\hline 11 & Candidatus Phytoplasma cirsii & KR869146.1 & \\
\hline 12 & Candidatus Phytoplasma convolvuli & JN833705.1 & \\
\hline 13 & Malaysian periwinkle virescence $M a P V$ & EU371934.2 & \\
\hline 14 & Candidatus Phytoplasma sudamericanum & GU292081.1 & \multirow[t]{2}{*}{81} \\
\hline 15 & Candidatus Phytoplasma costaricanum & HQ225630.1 & \\
\hline 16 & Mycoplasma feliminutum ATCC 25749 & FJ595091.1 & 79 \\
\hline 17 & Mycoplasma anseris & NR024977.1 & 75 \\
\hline 18 & Mycoplasma hyorhinis BTS7 & NR114563.1 & \multirow[t]{2}{*}{74} \\
\hline 19 & Mycoplasma salivarium & NR041745.1 & \\
\hline
\end{tabular}


Plate.1 Phyllody symptoms on naturally infected spikelets and inflorescence as compared to healthy spikelets and inflorescence of niger

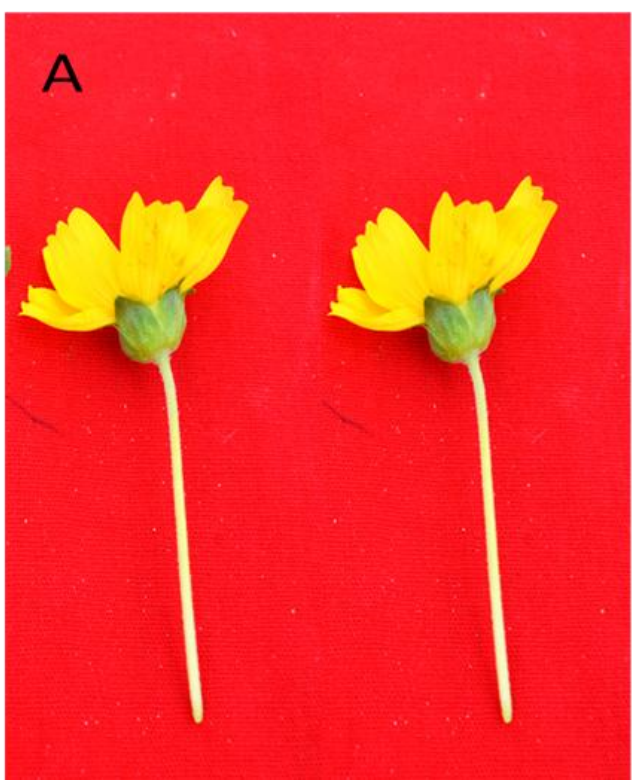

A: Healthy spikelets

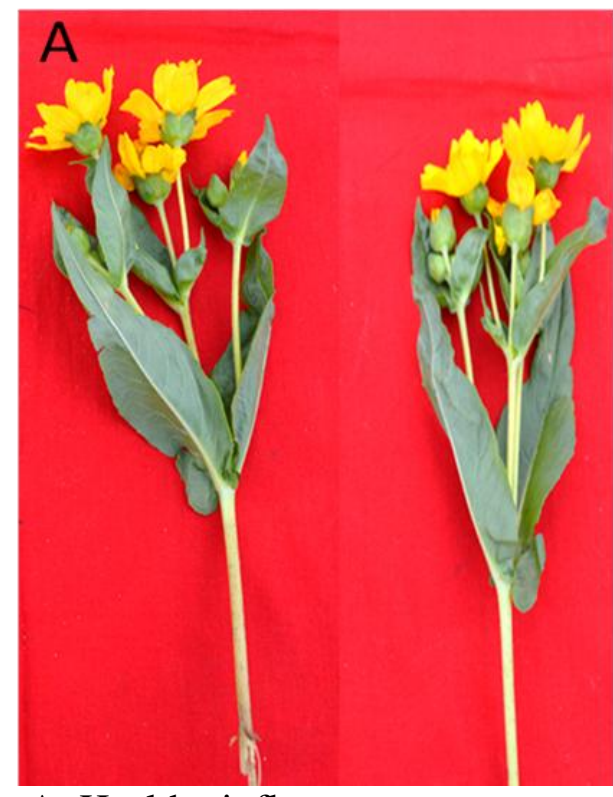

A: Healthy inflorescence

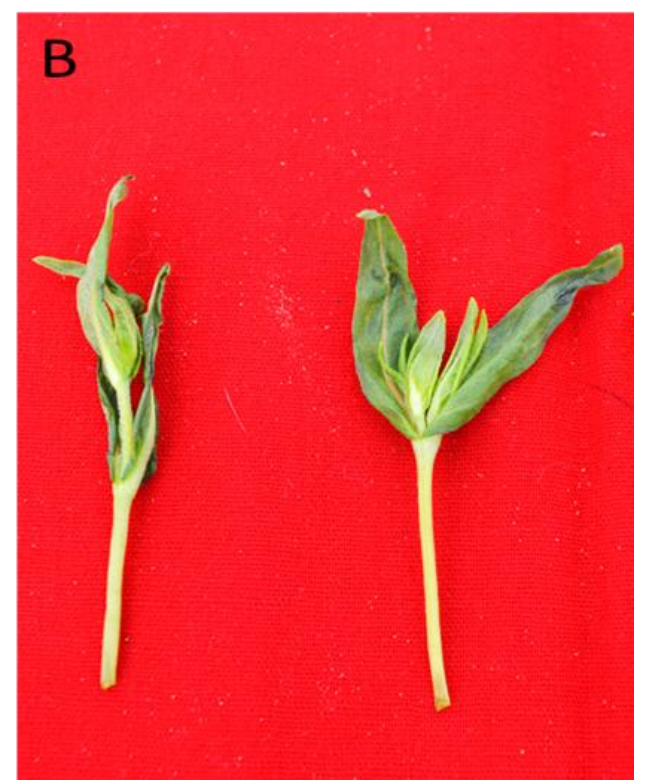

B: Infected spikelets

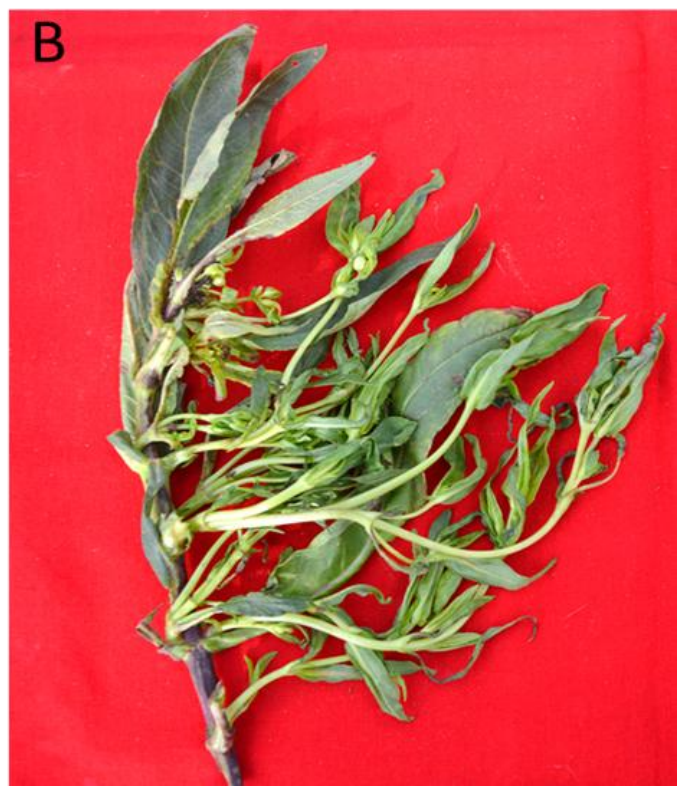

B: Transformed inflorescence 
Plate.2 Nested- PCR amplification of 16S rDNA of niger phyllody Phytoplasma Lane M: 1.5 kb Ladder, Lane 1, 2 and 3: Niger phyllody Phytoplasmal DNA, Lane 4 : Positive sample (Periwinkle phyllody), Lane 5: Healthy niger plant DNA

M

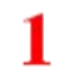

2
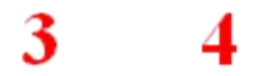

5

\section{$1.5 \mathbf{k b}$}

$1.0 \mathrm{kJl}$

$0.5 \mathrm{~kb}$

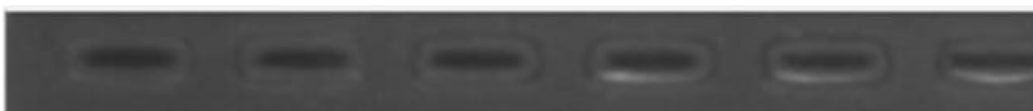

Figure.1 Phylogenetic tree constructed by maximum parsimony method using 16S rDNA sequences of niger phyllody Phytoplasma and other Phytoplasmal strains

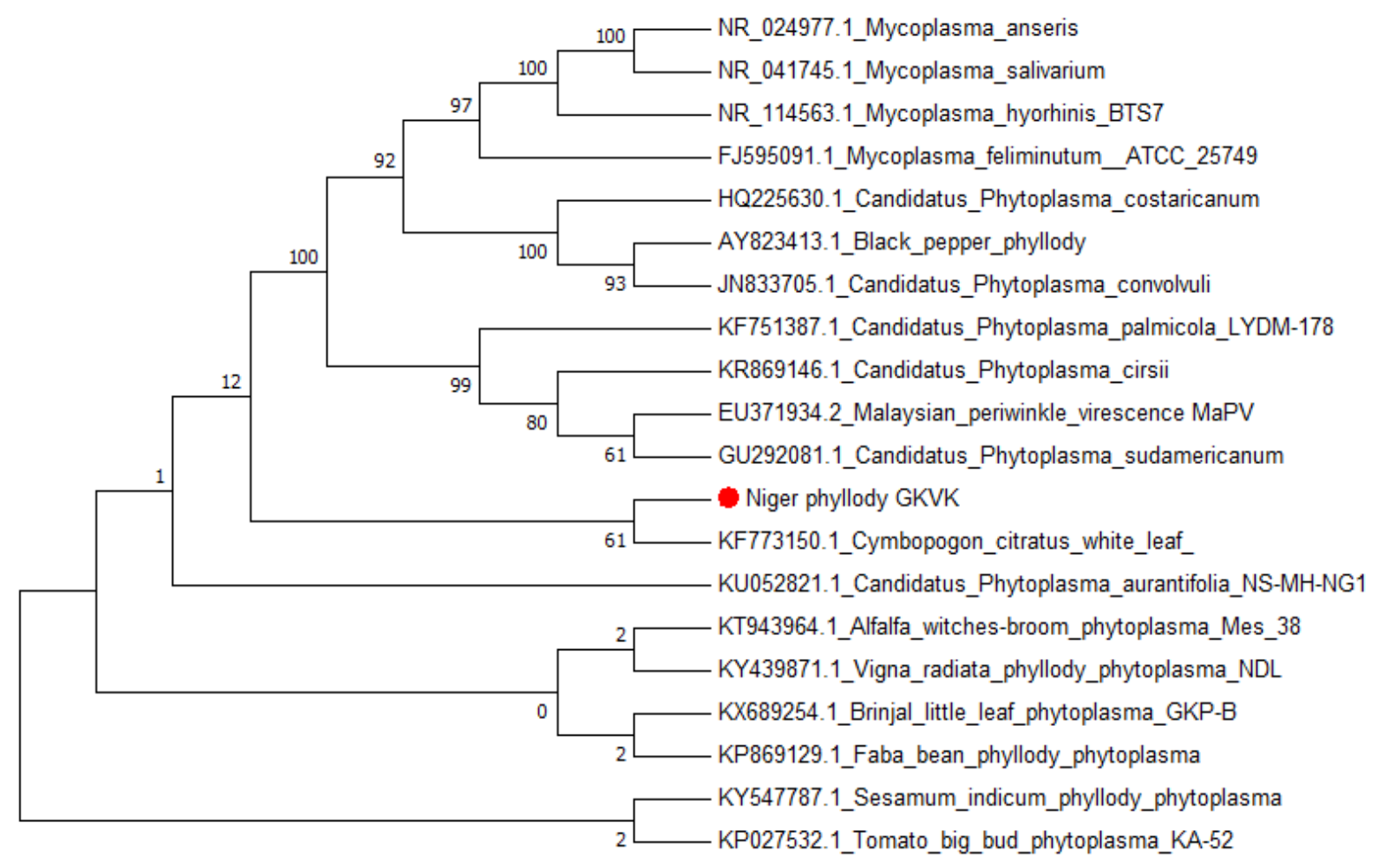


In the present study, niger phyllody Phytoplasma DNA was subjected to PCR amplification by using the universal primer P1/P7 which did not amplified the presence of Phytoplasma in infected and healthy niger plant samples or no visible product was amplified by PCR from samples obtained from niger phyllody and also in positive samples. This might be due to the presence of low level of DNA concentration below the detection in ethidium bromide-stained agarose gel. Further, first round PCR product was subjected to nested PCR, which yielded a DNA fragment of $1.2 \mathrm{~kb}$ in infected and positive control (periwinkle phyllody) but negative in asymptomatic plant. The present results are in agreement with the earlier work of Bhat et al., 2006; Kaminska et al., 2012; Madhupriya et al., 2013. It suggested the association of a Phytoplasma with the diseased plants. The nested primers are designed for the conserved region of the Phytoplasmas and found highly specific to the Phytoplasmal 16S rDNA.

Nested primer analysis using the primer pair R16F2n/ R16R2 greatly increases the sensitivity in detection of Phytoplasmas even when the Phytoplasma titters are very low and in which Phytoplasmas are unevenly distributed (Gundersen and Lee, 1996). Normal as well as nested PCR technique has been employed by various workers for the detection of Phytoplasma in the Phytoplasma affected crop plants (Lee et al., 1993; Raj et al., 2006). By nested PCR assay using universal primers R16F2n/ R16R2, a PCR product of $1250 \mathrm{bp}$ corresponding to the $16 \mathrm{~S}$ rDNA region of the Phytoplasma was detected indicating the association of Phytoplasmal agent in niger phyllody disease infected plant samples.

The 16S rDNA nucleotide sequence of niger phyllody Phytoplasma was compared with the $16 \mathrm{~S}$ rDNA gene sequences of other
Phytoplasmas obtained from NCBI database indicated that the Phytoplasma detected in niger phyllody disease shared maximum sequence similarity of 90 per cent with Cymbopogon citratus white Phytoplasma. Furthermore, the phylogenetic tree constructed also showed that niger phyllody Phytoplasma clustered with the Cymbopogon citratus white Phytoplasma which belonging to $16 \mathrm{SrII}$ group. This result was in agreement with earlier report of Naik et al., (2015) who investigated association of Phytoplasma with lablab bean and total DNA was used as a template for nested assay with universal primers that target the Phytoplasma 16S rRNA. The BLAST analysis of the partial 16S rDNA sequence showed the highest sequence identity (99 \%) with Phytoplasma of the group 16SrII 'Ca. Phytoplasma aurantifolia' that included isolates like the sesame phyllody Phytoplasma of subgroup 16SrII-D, tomato big bud, papaya yellow crinkle and papaya mosaic.

\section{References}

Anonymous, (2015a) Department of agriculture and cooperation ministry of agriculture govt. India. New Delhi. 22 pp.

Anonymous, (2015b) Karnataka state department of agriculture Bengaluru. 43pp.

Bhat, A. I., Madhubala, R., Hareesh, P. S. and Anandaraj, M. (2006) Detection and characterization of the Phytoplasma associated with a phyllody disease of black pepper (Piper nigrum L.) in India. Sci. Horti., 107: 200-204.

Deng, S. and Hiruki, D. (1991) Amplification of $16 \mathrm{Sr}$ DNA genes from culturable and non-culturable mollicutes. J. Microbial. Methods, 14: 53-61.

Gundersen, D. E. and Lee, I. M. (1996) Ultrasensitive detection of Phytoplasma by nested PCR assays using two universal 
primer pairs. Phytopatho. Mediter., 35: $144-151$.

Kaminska, M., Berniak, H. and Kaminski, P. (2012) Detection of 'Candidatus Phytoplasma asteris' in brussels sprout and Its possible association with flower bud failure in Poland. J, Life Sci., 6: 253-259.

Lee, I. M., Hammond, R. W., Davis, R. E. and Gundersen, D. E.(1993) Universal amplification and analysis of $16 \mathrm{~S}$ rDNA for classification and identification of mycoplasma like organisms. Phytopathol., 83: 834-842.

Madhupriya, Rao, G.P. and Khurana, S. M. (2013) 'Candidatus Phytoplasma asteris' association with leaf yellows and witches' broom symptoms of Brachycome species in India. Phytopatho. Mollicutes., 3 (2): 91-94.

Naik, K. V., Reddy, V. B., Rani, S. J., Prasanthi, L., Jayalakshmi, S. R., Shareef, M. S. and Krishna, G. T. (2015) Association of a 16SrII 'Candidatus Phytoplasma aurantifolia' isolate with bud proliferation disease of Lablab purpureus (lablab bean) in India. New Dis, Rep., 31: 31-37.

Raj, S. K., Khan, M. S., Snehi, S. K., Srivastava, S. and Singh, H. B. (2006) 'Candidatus Phytoplasma asteris' isolate associated with a little leaf disease of pigeon pea in India. Plant Pathol., 55: 823.

Rangaswamy, K. T. and Muniyappa, V. (1993) Natural occurrence of phyllody in niger in Karnataka state. Curr. Sci., 64(5): 281-282.

Smart, C. D., Schneider, B., Blomquist, C. L., Guerra, L. J., Harrison, N. A. and Ahrens, U., (1996) Phytoplasma specific PCR primers based on sequences of 16S-23SrRNAspacer region. Appl. Envir. Microbiol., 62, 2988-2993.

Sunard, M., Ben Khalifa, M., Marrakehiand Fakhfakh, (1991) Detection of Phytoplasma associated with Periwinkle virescence. Egyp. Pl. Pathol., 7 (1): 9297.

\section{How to cite this article:}

Mahalingappa Bandakkanavara, H. A. Prameela, Santosh Mali, S. Basavaraj, Manjunath, S. Hurakadli, Kedarnath and Rangaswamy, K.T. 2019. Molecular Detection and Characterization of Niger [Guizotia abyssinica (L.f.) Cass] Phyllody Phytoplasma. Int.J.Curr.Microbiol.App.Sci. 8(02): 1572-1579. doi: https://doi.org/10.20546/ijcmas.2019.802.184 